\title{
Indigenous wisdom of Ayurvedic drugs to treat Urinary tract infections
}

\author{
Review Article
}

\section{Prashant S Bhokardankar ${ }^{1}$, Bharat Rathi ${ }^{2 *}$}

1. Professor, Department of Rasashastra Bhaishajya Kalpana, Datta Meghe Ayurvedic Medical College Hospital and Research Centre, Nagpur, Maharashtra, India. 2. Professor, Department of Rasashastra Bhaishajya Kalpana, Mahatma Gandhi Ayurveda College Hospital and Research Centre, Salod (H.) Wardha, (MS), India.

\begin{abstract}
Urinary tract infections (UTI) in all ages are related with high morbidity and long term difficulties. Use of antibiotics is useful in cases of UTI, consequently opposition of pathogenic microorganisms to antibiotics is of high clinical concern. According to Ayurveda drugs especially important components which have been utilized for the treatment of various diseases. The review paper highlighted different clinical studies and scientific studies which are useful to prove the adequacy of Ayurveda drugs against urinary tract infections. Ayurvedic drugs were reviewed in the current paper in the awake of evaluating their well being for the clinical condition like UTI. Ayurvedic medications showed good anti bacterial properties against both gram positive and negative microscopic organisms causing UTI. Other aspects are highlighted likewise mitigating, diuretic, cell reinforcement, nephroprotective and antiurolithiatic properties helpful in the administration of UTI and all medications are protected even in high dosages subsequently can be adequately utilized for UTI conditions. In this paper an attempt is made to highlight the research work of herbal drugs of Ayurveda which would be effective in the treatment of UTI.
\end{abstract}

Key Words: Ayurveda, UTI, Ayurvedic drugs, Antibacterial.

\section{Introduction}

Urinary tract infection (UTI) is one of the major problem influencing individuals from all age groups including neonate to geriatric age. UTIs are among the most clinical condition causing infections through ought the world with significant clinical and money related burden(1). Consistently around 150 million individuals are being determined to have urinary tract contamination around the world. In an estimation, about $60 \%$ females and $13 \%$ males are suffered from UTI and other related conditions (2).

Clinically, UTI is classified into two classes, uncomplicated and complicated. Uncomplicated UTI generally influences a sound person with no basic or neurological urinary tract anomalies, which incorporates cystitis and pyelonephritis. Complicated UTI is an important condition creating various disorders like renal obstacles, may cause renal failure or even neurological issues(3). Females are progressively defenseless to UTI when contrasted with males due to the short length of urethra, nonappearance of prostatic emission, pregnancy and simple sullying of the tract with fecal flora(4). Escherichia coli is one of the most common form of bacteria causing UTI which represents up to $90 \%$ of

\section{* Corresponding Author:}

\section{Bharat Rathi}

Professor, Department of Rasashastra Bhaishajya

Kalpana, Mahatma Gandhi Ayurveda Medical College

Hospital and Research Centre,

Salod (H.) Wardha, Maharashtra, India

Email Id: bharatrathi174@gmail.com cases. Majority of UTI cases caused by the Escherichia coli (5)., and rest by Klebsiella, Enterobacter, Proteus, Pseudomonas, Enterococcus, Staphylococcus and others can likewise causes of UTI(6). Other bacteria are likewise proteus mirabilis, Klebsiella species, pseudomonas aeruginosa and Enterobacter species can cause less infections. Gram-positive organisms are less basic which incorporates Group B Streptococcus, Streptococcus aureus, streptococcus, saprophyticus and streptococcus, haemolyticus (7).

UTI portrays microbial colonization and disease of structures of the urinary tract. As per the modern science the organs included in urinary system are Kidney, Ureter, Bladder and Urethra and UTI affected by the picture of pyelonephritis, cystitis and urethritis. (8).Antibiotics are acting on microscopic organisms causing regular diseases expanding in all areas of the world(9). It is intriguing that example of obstruction watched differs from medical clinic to network, enormous emergency clinic to little clinic, state to state, and even shift from nation to country (10). Emergence of protection from antibiotics shows significance of utilizing proof based techniques for the treatment(11). Use of anti-microbial agents in patients with UTI appears to lessen length of emergency clinic remain and accordingly shows tolerant effects with their costs(12). Hence there is need of such drugs having improved efficacy with minimum or no side effects and cost effective derivatives for the use in UTI(13-14).

Number of herbal formulations has been developed in Ayurveda to treat UTI to compete with need of all time availability, easy dispensing, palatability and efficacy(15). In Ayurveda all the indications of UTI are 
described under the term 'Mutrakruchha'. Ayurveda has given prime significance to Mutravaha srotas and its vikaras (Urinary tract infection and its related disorder) Being a framework liable for homeostasis of liquids in the body it likewise detoxifies the body. In Mutraghata and Mutrakruchha, Kruchrata (dysuria)and Mutravibandha are at the same time present in any case, in Mutrakruchha there is predominance of Kruchhata (16). It is a Bastimarmagata vikara (disease) which is intricately referenced in Ayurvedic works of art and basti being one among the Trimarmas, the executives of disarranges identified with it has a more noteworthy restorative importance (17). Charak samhita explained various herbal plants like Gokshur, Vidarikand, Kamal, Neel kamal punarnava in UTI in Sutra sthan shadvirechan shata shritiya adhaya. Use of paniya ksharas are also suggested in urinary disorders (18). While Ashtang Hridaya explained drugs useful in UTI under mutraghat chikitsa.

\section{Aims and objectives}

Hence present study is aimed to review the Ayurvedic herbal drugs and their efficacy described in UTI.

\section{Materials and methods}

The internet search was done to find out scientific studies done on various Ayurvedic drugs as a usefulness as a potent urinary tract infection. Online database were used for the search of relevant ancient literature and research papers published. The key words used for the search were like Ayurveda, and therapeutic potential of Ayurveda herbal drugs. The research articles published in only English language were considered for the review. Ancient texts has been reviewed specially in the ancient Ayurvedic texts to find out the drugs mentioned having potential action in UTI.

\section{Observation and Results}

Table- 1. Herbal drugs mentioned in ancient Ayurvedic texts for UTI

\begin{tabular}{|c|c|c|c|c|}
\hline S.No. & Drugs Name & Latin Name & Part used & Reference \\
\hline 1 & Kamal & Nelumbo Nucifera [Garten] & Flower,Root & C.S.Su. $4 / 34$ \\
\hline 2 & Nil kamal & Nymphea nouchali [Garten] & Flower,Root & C.S.Su. 4/34 \\
\hline 3 & Yashtimadhu & Glycyrrhiza Glabra[L] & Bark & C.S.Su. $4 / 34$ \\
\hline 4 & Priynagu & Callicarpa Macrophylla[Vahl] & Fruit & C.S.Su. 4/34 \\
\hline 5 & Shatpatra & Rosa centifolia $[L]$ & Fruit,leaves & C.S.Su. $4 / 34$ \\
\hline 6 & Gokshur & Tribulus terrestris[L] & Fruit & C.S.Su. $4 / 35$ \\
\hline 7 & Punarrnava & Boerrhavia Diffusa[L] & Root,leaves & C.S.Su. $4 / 35$ \\
\hline 8 & Pashanbhed & Bergenia Ligulata (Wall) & Bark,root & C.S.Su. $4 / 35$ \\
\hline 9 & Kasa & Saccharum spontaneum[Linn.] & Root & C.S.Su. $4 / 35$ \\
\hline 10 & Vidarikanda & Pueraria tuberosa[Dc.] & Root & C.S.Su. $4 / 35$ \\
\hline 11 & Darbha & Desmostachya bipinnata[Stap.] & Root & C.S.Su. 4/35 \\
\hline 12 & Dhataki & Woodfordia fructicosa[L.] & Fruit & C.S.Su. $4 / 35$ \\
\hline 13 & Shobhanjan & Moringa oleifera[Lam.] & Bark,root & C.S.Su. $4 / 35$ \\
\hline 14 & Bala & Sida cordifolia [Burm.] & Root & A.H.Chi. $11 / 2$ \\
\hline 15 & Erand & Ricinus communis [Linn.] & Root & A.H.Chi.11/2 \\
\hline 16 & Kulattha & Vigna trilobata[L.] & Fruit & A.H.Chi. $11 / 2$ \\
\hline 17 & Yava & Hordeum vulgare [Linn.] & Root & A.H.Chi.11/9 \\
\hline 18 & Kantakari & Solanum xanthocarpum[Scharad.] & Panchang & A.H.Chi. $11 / 11$ \\
\hline 19 & Paribhadra & Erythrina indica[Lamk.] & Kshar & A.H.Chi. $11 / 14$ \\
\hline 20 & Ashmantak & Sesbania Grandiflora. [Linn.] & Leaves & A.H.Chi. $11 / 15$ \\
\hline 21 & Atibala & Abitulon indicum[Link.] & Root & A.H.Chi.11/18 \\
\hline 22 & Ushir & Vetiveria zizanioides (L.) Nash & Root & A.H.Chi.11/18 \\
\hline 23 & Bhallatak & Semecarpus indicum[Linn.] & Fruit & A.H.Chi.11/18 \\
\hline 24 & Katphala & Myrica nagi[Thumb] & Fruit & A.H.Chi. $11 / 19$ \\
\hline 25 & Shalimoola & Desmodium gangeticum[D.C.] & & A.H.Chi.11/22 \\
\hline 26 & Patala & Stereospermum suaveolens[D.C.] & Root & A.H.Chi. $11 / 23$ \\
\hline 27 & Patha & Cissampelos pareira[Linn.] & Root & A.H.Chi. $11 / 23$ \\
\hline 28 & Shirish & Albizia lebbeck [L.] & Bark & A.H.Chi. $11 / 23$ \\
\hline 29 & Guggul & Commiphora mukul[Hook.ex.Stocks] & Gum & A.H.Chi. $11 / 25$ \\
\hline 30 & Marich & Piper nigrum [Linn.] & Fruit & A.H.Chi. $11 / 25$ \\
\hline 31 & Kushta & Saussuera lappa[C.B.Clarke.] & Root & A.H.Chi. $11 / 25$ \\
\hline 32 & Chitrak & Plumbago zeylanica[Linn.] & Root & A.H.Chi.11/25 \\
\hline 33 & Haritaki & Terminalia chebula[Retz.] & Fruit & A.H.Chi. 11/33 \\
\hline 34 & Shatavari & Asparagus racemosus/Willd.] & Root & Y.Chi.Mutrakruccha 4-5 \\
\hline 35 & Bruhati & Solanum indicum $[L]$ & Panchang & Y.Chi.Mutrakruccha 4-5 \\
\hline 36 & Sunthi & Zingiber officinale [Roscoe ] & Root & Y.Chi.Mutrakruccha 4-5 \\
\hline 37 & Amalaki & Emblica officinalis [Garten.] & Fruit & Y.Chi.Mutrakruccha 4-5 \\
\hline
\end{tabular}

C.S.Su.Shad. —Charak Samhita, Sutra sthan, A.H.Chi.Ashtang hruday, Chikitsa adhyaya,

Y.Chi.Mutrakruccha-Yogratnakar Chikitsa sthan Mutrakruchha adhyay) 
International Journal of Ayurvedic Medicine, Vol 11 (3), 370-377

\begin{tabular}{|c|c|c|c|}
\hline S.no. & Name of the formulation & Indications & Reference (text) \\
\hline 1 & Trinetrakhya Ras & Mutrakrucha (UTI) & R.S.Mu.Chi.1-2 \\
\hline 2 & Varunadi lauh & $\begin{array}{c}\text { Mutrakrucha (UTI), Ashmari } \\
\text { (Calculi) }\end{array}$ & R.S.Mu.Chi.3-6 \\
\hline 3 & Mutrakruchhantak Ras & Mutrakruchha (UTI) & R.S.Mu.Chi.10-12 \\
\hline 4 & Trunpanchmula & Mutrakruchha (UTI) & B.R. Mu.Chi.10 \\
\hline 5 & Gokshur kwath & Mutrakruchha (UTI) & B.R.Mu.Chi.13 \\
\hline 6 & Haritakyadi yog & Mutrakruchha (UTI) & B.R.Mu.Chi.20 \\
\hline 7 & Duralabhadi kashaya & Mutrakruchha (UTI) & B.R. Mu.Chi.28 \\
\hline 8 & Eladi Churna & Mutrakruchha (UTI) & B.R. Mu.Chi.30 \\
\hline 9 & Tarkeshwar Ras & Mutrakruchha (UTI) & B.R. Mu.Chi.35 \\
\hline 10 & Varundya Lauh & Mutrakruchha (UTI), Bal vardhak & B.R. Mu.Chi.66 \\
\hline 11 & Chandrakala Ras & Mutrakruchha (UTI) & B.R. Mu.Chiki.67-75 \\
\hline
\end{tabular}

R.S.Mu.Chi.-Rasendra sarsangrha Mutrakruchha chikitsa adhyay, B.R. Mu.Chi.-Bhaishjya ratnavali Mutrakruchha chikitsa adhyay

\section{Researches on Ayurvedic herbal drugs useful in UTI Allium sativum (Lahsun)}

A Kumar et al, studied the antibacterial activity of allicin from Allium sativum against antibiotic resistant uropathogens. Lahasun (A. sativum) was examined by circle dissemination technique against gram-positive and gram negative bacteria and results were found good for urinary tract of infections of patients(19) . E.Y. Sukandar et al stated that at higher portion allium sativum even have no critical antagonistic occasion with no reaction on kidney and liver capacities just as the blood composition (20).

\section{Coleus aromaticus (Pashanbhed)}

Rashmi Sahay Khare et al, studied that the oils of Pashanbhed have a good antibacterial activity with minimal inhibitory concentration (MIC) ranging from $0.5 \mu 1 / \mathrm{ml}-6 \mu 1 / \mathrm{ml}(21)$. Govindaraju Subramaniyan et al studied Pashanbhed can act against both Gram positive (Bacillus subtilis, Staphylococcus aureus, Enterococcus faecalis) and Gram negative (Escherichia coli, Shigella sonnei, Pseudomonas aeruginosa, Klebsiella pneumoniae, Proteus vulgaris) causing UTI (22).

\section{Crataeva nurvala (Varun)}

Crataeva is likewise shown for ceaseless diseases of the urinary framework. Deshpande PJ et al in one a clinical report the larger part $(85 \%)$ of patients with demonstrated interminable urinary tract contaminations were among indication in following a month of treatment with Crataeva decoction (23). Agrawal et al observed that the exploratory examination with decoction of Crataeva nurvala, it was uncovered that the medication is viable in the administration of urolithiasis which is viewed as one of the inclining factor for UTI (24). Bhattacharjee Atanu et al stated that there is no watched unfavorable impacts level (NOAEL) estimation of $2000 \mathrm{mg} / \mathrm{kg}$ body weight suggests that the medication is safe (25).

\section{Coriandrum sativum (Dhanyak)}

Abderahim Aissaoui et al were studied that the crude aqueous extract of coriander sativum was drastically increased diuresis, excretion of electrolytes, and glomerular filtration rate in a dose-dependent way.The mechanism of action of the plant extract was compared with the modern drug furosemide. (26).

\section{Hemidesmus indicus (Sariva)}

Ratha et al observed that the H.indicus ethanolic root separate demonstrated most extreme zone of restraint against escherichia coli(27). M Gayathri et al studied that,it act as a antibacterial action against staphylococcus aureus, pseudomonas aeruginosa, klebsiella pneumoniae(28). Navneet B. Gadge et al found that single oral portion of watery and ethanolic concentrate of $H$. indicus root $(200 \mathrm{mg} / \mathrm{kg}$ and $400 \mathrm{mg} /$ $\mathrm{kg}$ per oral (p.o.) each) demonstrated the medication as diuretic agent(29). Kotnis M S et al in their study revealed that Hemidesmus indicus root was assessed against gentamycin incited renal toxicity and found that the lines demonstrating its Reno-defensive activity(30). Atal et al stated that the medicate is very protected at restorative portion. LD50 was seen as $2500 \mathrm{mg} / \mathrm{kg}(31)$.

\section{Moringa oleifera (Shigru)}

Karandikar GK et al Studied that Shigru decoction is a compelling solution for symptomatic help in UTIs because of the antibacterial and calming operators present in the plant(32). Dr B Akila et al and $\mathrm{T}$ Rastogi et al revealed that stem bark of $M$. oleifera has been tried against an assortment of microorganisms like escherichia coli, staphylococcus aureus, bacillus. cereus, pseudomonas aeruginosa, and proteus mirabilis. It shows useful impact against escherichia coli(33-34). F. J. Vijayalakshmi, et al analyzed the antiurolithiatic activity of aerial extracts of Shigru(35). Chetia et al observed that the effect of Shigru is good in urinary tract infection(36) .M Gul et al studies the Cell reinforcement activity of shigru (37). C pinar et al observed that the bark is compelling against oxidative stress created in UTI on account of phenolic component(38). M. R. Kumbhare et al estimated the of total phenolic content, cytotoxicity and invitro antioxidant activity of stem bark of Moringa oleifera. It was found that it repress adherence of microorganisms to the mass of the bladder by sloughing them off in urine(39). 


\section{Nelumbo nucifera (Kamal)}

Chopra described in his book the useful part of Kamal is rhizome(40) while Mukherjee P. K et al described the flowers having medicinal property (41) and as well as have great diuretic properties(42). Brindha $\mathrm{B}$ et al observed that its rhizome, leaves and stem of the plant have antibacterial properties(43).Venkatesh B et al and $\mathrm{Ou} \mathrm{M}$ were studied that the kamal is having powerful against numerous gram negative microscopic organisms causing urinary tract infections(44-45).Ku Lee et al suggested that the leaves were seen as compelling in the administration of hematuria (46). $\mathrm{Wu} \mathrm{Mj}$ et al observed that the kamal act as a cancer prevention agent due to lotus alcohol produced using leaves and flowers(47) and rhizome additionally have great cancer prevention agent properties (48). Srivastava et al studied that the root extract of Nelumbo nucifera improves kidney work against gentamicin initiated nephrotoxicity(49). Nguyen Q suggests that its stems is very useful as nephro protective $\operatorname{drug}(50)$. Kuo $\mathrm{YC}$ et al; had been studied the antimicrobial properties of Blossoms of N. nucefera have demonstrated it to be compelling against Staphylococcus aureus, pseudomonas aeruginosa, bacillus subtilis(51). Kashiwada $Y$ et al observed that in pediatric age of patients viral UTI may happen in immune compromised youngsters, particularly herpes zoster may give cystitis and lower urinary tract infections, Nelumbo nucifera was useful in this type of patients(52). Kunanusorn $\mathrm{P}$ et al, studied the properties against the escherichia coli, enterococcus faecalis, xanthomonas campestris, streptococcus mutans, lactobacillus casei and lactobacillus acidophilus(53).

\section{Nymphea nouchali (Neelkamal)}

Vasu K et al observed that the Neel kamal ethanolic concentrate of leaves has demonstrated extensive antibacterial action against escherichia . coli(54), K.Ammani et al studied the mitigating activity accordingly demonstrating it to be a viable medication against UTI (55). Mohan Maruga et al observed that no huge treatment related changes in any hematological or serological parameters or then again toxicity was seen for the plant(56).

\section{Solanum xanthocarpum (Kantakari)}

It posses antimicrobial activity against all the bacterial species specially escherichia coli and least against klebsiella pneumoniae (57) .Alcohol, acetone and petroleum ether extract of kantkari stem, leaf and fruits kantkari exhibited potent antibacterial activity against klebsiella pneumoniae and salmonella typhi. (58). S.xanthocarpum methanolic fruit extracts at 5, 10 and $15 \mathrm{mg} / \mathrm{ml}$ showed significant inhibition against bacteria and fungi less than ampicillin or amphotericin $\mathrm{B}(59)$.

\section{Tribulus terrestris (Gokshur)}

Goskshur was traditionally used by ayurvedic vaidyas as a mild laxative,diuretic, urolithiasis, dysurea for treatment of urinary tract problems including cystitis ,stones and infections. Anitha.K et al studied the all parts of T. terrestris in center Asia appeared antibacterial movement against enterococcus faecalis, streptococcus,aureus, escherichia coli and pseudomonas aeruginosa(60). Anita et al as well as Abbasoglu U et al, observed that foods grown from the ground of Indian $T$. terrestris were dynamic solely against escherichia . coli and streptococcus aureus (60-61).Williamson EM et al studies the decoction (kwatha) of Gokshur was concentrated against gentamycin induced renal toxicity in albino rats and end up being a compelling nephroprotective function(62). Nagarkatti D.S et al observed it's powerful diuretic action (63). Singh R G studied the decoction of natural product in rats and alcoholic concentrate in albino rats were displayed diuretic effect(64). Gujral M.L. et.al,studied the toxicity of the drug ,so it shown as a safe drug (65).

\section{Terminalia chebula (Haritaki)}

Tariq A. L. et al observed that ethanolic concentrate and acetone concentrate of product of $\mathrm{T}$. chebula were act against proteus vulgaris. Both the concentrates showed great antimicrobial action against UTI related with proteus vulgaris(66). Chattopadhyay $\mathrm{RR}$ et al, revealed that T.chebula concentrate act as antimicrobial agent against escherichia coli, pseudomonas aeruginosa, shigella flexineria, and streptococcus aureus(67) . Khan KH studied the toxicity of T.Chebula and observed that no toxicity and come to the conclusion that it's safe drug (68). Studies conducted by Sumit et. al reveals that Terminalia chebula can act against staphylococcus aureus, bacillus subtilis, escherichia coli.,streptococcus,agalactiae, streptococcus uberis, salmonella and pseudomonas aeruginosa at the interval of 24, 36, and 48 hours. (69).

\section{Researches on polyherbal formulations Chandanadi Churna}

D. H. Tambekar et al,studied this drug in genitourinary diseases and found that it has powerful antibacterial movement against proteus vulgaris, klebseilla pneumoniae, escherichia coli, pseudomonas aeruginosa and staphylococcus aureus (70).

\section{Chandanasava}

Pravin kumar et al., have studies it's antibacterial property particularly compelling against escherichia coli and found it's useful (71).Pankaj dixit found that it has a alkalizing activity(72).S.Sekar et al, revealed it's diuretic property and Chandnasava is a powerful medication against UTI (73). Annadurai Vinothkanna et al, studied it's use in pediatrics and come with inference that it can be utilized successfully among pediatric age group(74) .

\section{Punarnavasava}

Manisha Gharate et al studied the property of Punarnavasava as antipyretic(75).Mehdi Bin et al studied it as a analgesic(76). Vineeth $\mathrm{T}$ et al observed that it can be act against proteus, klebsiella, pseudomonas, escherichia coli, enterococcus. In addition no any harmfulness was noted with its utilization. In this manner demonstrating it to be a 
protected medicine in UTI in all age bunch including children(77).

\section{Shweta parpati}

Priya Bhat et al, observed that in lower urinary tract infection shweta parpati was given for 15 days in a 40 patients and the drug has shown marked relief for the symptoms. (78).

\section{Trinapanchamula kwatha}

It is a compelling tranquilize usually utilized in urinary related infirmities in Ayurveda. S. Jayalakshmi et al, had been studied the antibacterial property of Trinapanchamula kwatha particularly against staphylococcus aureus, escherichia coli, mariniluteicoccus flavus, pseudomonas aeurogenosa, bacillus subtilis(79).Jitendra D. Khot et al stated that the antibacterial property it further assistance with symptomatic alleviation in UTI by righteousness of its job in mitigating consuming micturition, decrease of epithelial cells and discharge cells in urine(80).S Jayalaksmi et al determined the antipyretic property of Trinapanchamula kwatha(81).

\section{Ethno-medicinal uses of herbal drugs used in UTI}

Herbal drugs used by traditional healers play vital role to combat Urinary tract disorders in remote areas as they are safe, effective, inexpensive and easily available. Most of the tribes reside at remote villages have a deep knowledge of medicinal plants and collect the plants from adjoining forest areas for the treatment of local population( 82). Number of ethno medicinal survey studies conducted in India revealed the uses of herbal drugs by traditional healers in UTI. Chauhan et al describe the use punarnava root decoction in urinary stones (83). Sundaran et al found Rhizome Extract of Zingiber officinale used for Renal failure where as Abutilon indicum root powder is used as nephroprotective by the traditional healers (84). Narsingh Varma et al clinically tested that Gokshurdai yog is useful in early stages of urinary tract infection and gives symptomatic relief to the patients. (85)

\section{Discussion}

UTI is an important clinical disorder in all ages and in both sex around the world. Despite the fact that few antibiotics agents are useful for the treatment. But the issue of medication is resistance and side effects due to long term utilization of drugs are very normal. Taking into consideration, the review of Ayurvedic drugs in UTI is done. Ayurveda drugs are help out in positive way and negligible side effects with less toxicity. The Ayurvedic drugs has been shown altogether powerful in controlling and mitigating clinical issues of E. coli, Klebsiella and B. proteus and mostly gram positive and gram negative microbes which can cause the UTI. The herbs like $T$. terrestris, Craeteva narvula etc do not cause loss of discharge of electrolytes as it may happen with different diuretics. Ayurvedic herbs as well as Ayurvedic formulations are helpful to improve the condition of UTI like dysuria and expanded recurrence.
The gainful reaction of medication was seen inside multi week of treatment and no untoward impacts were watched over the span of treatment. In this way, it can be presumed that Ayurvedic drugs are prudent, safe in the administration for UTI Patients.

\section{Conclusion}

The current review involves that these Ayurveda drugs have antibacterial, cancer prevention agents, nephroprotective, alkalizing, diuretic, mitigating and hostile to urolithiatic properties with no harmfulness or symptoms and entanglements in both straightforward or multi tranquilize safe in UTI. These medications will deal with the UTI and furthermore decrease the odds of agonizing prick of anti-microbial. In this manner particular and cautious utilization of these Ayurveda drugs will end up being useful in UTI .Further research especially clinical data needs to be generated for wide use of these drugs and so called as evidence based medicines.

\section{References}

1. Ana L. Flores-Mireles, Jennifer N. Walker.Urinary tract infections: epidemiology, mechanisms of infection and treatment options. Nat Rev Microbiol. 2015;13(5):269-284.

2. Cardwell SM, Crandon JL, Nicolau DP, McClure MH, Nailor MD. Epidemiology and economics of adult patients hospitalized with urinary tract infections. Hosp Pract (1995) 2016;44:33-40

3. Singh Randhir K, Dewasy Bijoylakshmi.Prevalence of antibiotic sensitivity pattern of uropathogens in patients of different age-groups from western region of Nepal. International Journal of Medical Research \& Health Sciences.2016;5(9):1-7.

4. Loh KY, Sivalingam N.Urinary Tract Infections in Pregnancy. Malaysian Family Physician 2007; Volume 2, Number 2.

5. Ejrnæs K. Bacterial characteristics of importance for recurrent urinary tract infections caused by Escherichia coli. Dan Med Bull 2011;58:B4187.

6. Nalini R, J Ezhil Ramya.Recent Sensitivity Pattern of Escherichia Coli in Urinary Tract Infection. RRJMB.2014;3(3).

7. Gupta S, Kapur S, Padmavathi D. Comparative prevalence of antimicrobial resistance in community-acquired urinary tract infection cases from representative states of Northern and Southern India. J Clin Diagn Res 2014;8:DC09-12.

8. Sawarkar GR. Anatomical study of mūtravaha srotasa with special reference to mūtrakruchhra. Journal of Indian System of Medicine. 2013 Jan 1;1(1):35.

9. Farajnia S, Alikhani MY, Ghotaslou R, Naghili B, Nakhlband A. Causative agents and antimicrobial susceptibilities of urinary tract infections in the Northwest of Iran. Int J Infect Dis 2009;13:140-4.

10. Nickel JC. Management of urinary tract infections: Historical perspective and current strategies: Part 2 - modern management. J Urol 2005;173:27-32. 
11. Spoorenberg V, Hulscher ME, Akkermans RP, Prins JM, Geerlings SE. Appropriate antibiotic use for patients with urinary tract infections reduces length of hospital stay. Clin Infect Dis 2014;58:164-9

12. Sharma N, Gupta A, Walia G, Bakhshi R. Pattern of antimicrobial resistance of Escherichia coli isolates from urinary tract infection patients: A three year retrospective study. J Appl Pharm Sci 2016;6:62-5. 9. Naber KG,

13. Schito G, Botto H, Palou J, Mazzei T. Surveillance study in Europe and Brazil on clinical aspects and antimicrobial resistance epidemiology in females with cystitis (ARESC): Implications for empiric therapy. Eur Urol 2008;54:1164-75.

14. Sri Madavakara Madhava nidana of Sanskrit text and madhukosa commentary with English translation part 1 by Dr. P.Himasagara Chandra murthy, chaukhamba Sanskrit series office,30thchapter Mutrakruchranidana,1-2 sloka, page number 146

15. Rathi B, Rathi R. Pharmaceutico-analytical Standardization of Triphala Mouthwash. Journal of Indian System of Medicine. 2017 ;5(1):30-35

16. Acharya YT, editor, Charaka Samhita of Agnivesha., Chikitsa Sthana 26/3-4, Choukambha Sanskrit Sansthan,Varanasi, reprint edition 2004, p 597.

17. Acharya YT, editor, Charaka Samhita of Agnivesha., Chikitsa Sthana 26/37, Choukambha Sanskrit Sansthan,Varanasi, reprint edition 2004, p 597.

18. Rathi B, Pharmaceutical and Analytical Study on Panaviraladi Kshara, Journal of Indian System of Medicine, 2014; 2(1): 35-38

19. Kumar A, Sharma V. Antibacterial activity of allicin from Allium sativum against antibiotic resistant uropathogens. The Internet Journal of Infectious Diseases 2009: 8(1).

20. Sukandar EY, H. Permana, I.K. Adnyana, J.I. Sigit, R.A. Ilyas, P. Hasimun et.al. Clinical Study of Turmeric (Curcuma longa L.) and Garlic (Allium sativum L.) Extracts.

21. Rashmi Sahay Khare, Sourish Karmakar, Shanta Banerjee, Gopal Nath, Subir Kundu and Kanika Kundu. Uropathogen resistant essential oils of coleus aromaticus and ocimum sanctum. IJPSR 2011; 2(8): 2168-72.

22. Govindaraju Subramaniyan, Indra Arulselvi Padikasan. In vitro Antioxidant, Antibacterial Activity of C. aromaticus Essential Oil against Multidrug Resistant (MDR) Urinary Tract Infected Pathogens. IJPPR 2014-15; 6(4): 996-1001

23. Deshpande PJ. Crataeva nurvala hook and forest (Varun)-the Ayurvedic drug of choice in urinary disorders. Indian J Med Res 1982; 76(Suppl): 46

24. Agarwal S, Gupta SJ, Saxena AK, Gupta N, Agarwal S. Urolithic property of Varuna (Crataeva nurvala): An experimental study. Ayu. 2010; 31(3): 361-6.

25. Bhattacharjee Atanu, Shashidhara Shastry Chakrakodi, Saha Santanu. Evaluation of Acute and
Sub-Chronic Oral Toxicity Study of Ethanolic Extract of Crataeva nurvala Buch-Ham Stem Bark on Experimental Wistar Rats. Research J of Pharmacognosy and Phytochemistry 2013; 5(6):293-6.

26. Abderahim Aissaoui, JaouadEl,HilalyZafar H.Israili, Badiâa Lyoussi, Journal of Ethnopharmacology, Vol.115, Is sue - 1, 4 th Jan.2008,Pages-89-95.

27. Ratha, M, Subha. K, Senthilkumar. G and Panneerselvam. A Screening of phytochemical and antibacterial activity of Hemidesmus indicus (L.) and Vetiveria zizanoides (L.) Euro. J. Exp. Bio. 2012; 2 (2):363-8

28. Gayathri M \& KannabiranK, Antimicrobial activity of Hemidesmus indicus, Ficus bengalensis andPterocarpus marsupium roxb Indian J Pharm Sci. 2009; 71(5): 578-81.

29. Navneet B. Gadge and Sunil S. Jalalpure. Natriuretic and saluretic effects of Hemidesmus indicus $\mathrm{R}$. Br. Root extracts in rats. Indian $\mathrm{J}$ Pharmacol. 2011; 43(6): 714-717.

30. Kotnis MS, Patel P, Menon SN, Sane RT. Renoprotective effect of Hemidesmus indicus, a herbal drug used in gentamicin induced renal toxicity. Nephrology (Carlton) 2004;9:142-52.

31. Atal, C.K., M.L. Sharma, A Kaul and A Khajuria. Immunomodulating agents of plant origin. I. Preliminary screemng. J. Ethnopharmacol. 1986;18:133-41.

32. Karandikar GK. Effect of some Ayurvedic remedies on the urine output in rats and dogs. Ind Jour Med sciences $1960 ; 14$ : 585-9.

33. Akila B, Manickavasakam K. Oral acute and subacute toxicity studies of two siddha formulations Vedikara silasathu parpam (vsp) and nerunjil kudineer (nk) in experimental rats. Int J Pharm Pharm Sci 2012; 4(2):88- 90.

34. Rastogi T, Ghorpade DS, U. A. Deokate, and S. S. Khadabadi, Studies on antimicrobial activity of Boswellia serrata, Moringa oleifera and Vitex negundo: a comparison. Research Journal of Pharmacognosy and Phytochemistry 2009; 1(1): 75-77.

35. Vijayalakshmi FJ, M. C. S. Kumar, G. P. Kodancha, B. Adarsh, A. L. Udupa, and U. P. Rathnakar. Antiurolithiatic activity of aqueous extract of bark of Moringa oleifera (Lam.) in rats. Health 2010; 2(4): 352-5.

36. Chetia B and S. Gogoi. Antibacterial activity of the methanolic extract of stem bark of Spondias pinnata, Moringa oleifera and Alstonia scholaris. Asian Journal of Traditional Medicines 2011; 6(4): $163-7$

37. Gul M, E. Kurutas, P. Ciragil. Urinary tract infection aggravates oxidative stress in diabetic patients. The Tohoku Journal of Experimental Medicine 2005; 206(1): 1-6.

38. Pinar, B. K. Ergul, G. Mustafa, K. Metin, A. Murat, and G. Alanur. The effects of oxidative stress in urinary tract infection during pregnancy. Mediators of Inflammation 2005; 5:309-11. 
39. Kumbhare MR, V. Guleha, and T. Sivakumar. Estimation of total phenolic content, cytotoxicity and invitro antioxidant activity of stem bark of Moringa oleifera. Asian Pacific Journal of Tropical Disease 2012; 2(2):144-50.

40. Chopra RN. Glossary of Indian Medicinal Plants. Council of Scientific and Industrial Research: New Delhi 1956; 174.

41. Mukherjee P. K., Das J., Saha K., Giri S. N., Pal M., Saha .B.P. Antipyretic activity of Nelumbo nucifera rhizome extract. Indian Journal of Experimental Biology 1996; 34(3):275-6

42. Mukherjee, P.K. Quality Control of Herbal Drugs An Approach to Evaluation of Botanicals. 1st Edition, Business Horizons, New Delhi, India 2002; 250-254.

43. Brindha B, Arthi D. Antimicrobial activity of white and pink Nelumbo nucifera Gaertn flowers. Asian journal of pharmaceutical research and health care 2010; 2(2).

44. Venkatesh B, Dorai A. Antibacterial and Antioxidant potential of White and Pink Nelumbo nucifera Gaertn Flowers. IACSITPress Singapore 2011; 5:213-217.

45. Ou M. Chinese-English Manual of Commonly-used in Traditional Chinese Medicine. Joint Publishing Co Ltd Hong Kong 1989.

46. Ku-Lee H, Mun-Choi Y, Ouk-Noh D, Joo-Suh H. Antioxidant effect of Korean traditional Lotus liquor (Yunyupju). International Journal of Food Science \& Technology 2005; 40:709-787.

47. Wu MJ, Wang L, Weng CY, Yen JH. Antioxidant activity of methanol extract of the lotus leaf (Nelumbo nucifera Geartn.). Am J Chinese Med 2003; 31:687-98.

48. Hyun SK, Jung YJ, Chung HY, Jung HA, Choi JS. Isorhamnetin glycosides with free radical and ONOO scavenging activities from the stamens of Nelumbo nucifera. Arch Pharm Res 2006; 29:287-292.

49. Srivastava. Nephroprotective activity of nelumbo nucifera gaertn. roots, leaves and flowers on gentamicin induced nephrotoxicity. AJPER 2014; 3(4): 134-51

50. Nguyen Q. Lotus A new crop for Australian horticulture. IHD: Access to Asia Newsletter1999; (2):1-5. http://www.nre.vic.gov.au/trade/asiaveg/ nlaf-04c.htm assessed on 10/05/2015

51. Kuo YC, Lin YL, Liu CP, Tsai WJ. Herpes simplex virus type 1 propagation in HeLa cells interrupted by Nelumbo nucifera. J Biomed Sci 2005; 12:1021-34.

52. Kashiwada Y, Aoshima A, Ikeshiro Y, Chen YP, Furukawa $H$, Itoigawa $M$ et al. Anti-HIV benzylisoquinoline alkaloids and flavonoids from the leaves of Nelumbo nucifera, and structure activity correlations with related alkaloids. Bioorg Med Chem 2005; 13:443-48.

53. Kunanusorn P, Panthong A, Pittayanurak P, Wanauppathamkul S, Nathasaen N, Reutrakul V. Acute and subchronic oral toxicity studies of
Nelumbo nucifera stamens extract in rats. J Ethnopharmacol. 2011 Apr 12;134(3):789-95.

54. Vasu K, Singaracharya MA. Antimicrobial activity of certain aquatic angiosperms against some pathogenic bacteria. Asian J Microbiol Biotechnol Environ Sci 2008;10: 609-13.

55. Ammani K, A.Kiran Kumar, sai babu. Antimicrobial and phytochemical analysis of nymphaea nauchali leaf extracts. Ijrrpas 2013 , 2(2).142-151

56. Mohan Maruga Raja MK, Dhanabal SP, Patil MJ. Pharmacognostical investigation and antibacterial activity of Nymphaea stellata Willd. Leaves. Hamdard Med 2008; 51:139-45.

57. Udaykumar R, Velmurugan, K, Srinivasan D, Krishna RR. Phytochemical and antimicrobial studies of extracts of Solanum xanthocarpum. Anc Sci Life 2003; 23(2): 90-94).

58. Abbas K, Niaz U, Hussain T, Saeed MH, Javaid Z, Idrees A, Rasool S. Antimicrobial activity of fruits of Solanum nigrum and Solanum xanthocarpum. Acta Poloniae Pharmaceutica -Drug Research 2014; 71(3): 415-21.)

59. Amin AH Mehta DR, Samarth SS. In: Proceedings, First International Pharmacological Meeting, Stockholm, Pergamon Press Ltd.

60. Anitha.K, Ranjith.K, Vakula.K, Thirupathi.G, B.Balaji. Acute and chronic toxicity studies of petroleum ether extract of nymphaea nouchali in experimental animals. Inter. J. of Pharmacotherapy 2012; 2(1): 24-28.

61. Abbasoglu U, Tosun F. Antimicrobial activity of Tribulus terrestris L. growing in Turkey. Hacettepe Universitesi Eczacilik Fakultesi Dergisi. 1994;14:81-85.

62. Williamson EM. Major Herbs of Ayurveda. China: Churchill-Livingstone 2002: 312.Khosale Vijay.Thesis - Gokshuru ka guna karmathmaka adhyayanevam moothra krichra par prabhav. Baba Farid University of health sciences 1991

63. Nagarkatti D.S., Rege N., Mittal, B,V., Uchil D.A., Desai,N.K. and Dhanukar S.A. Nephroprotection by Tribulus terrestris. Update Ayurveda Mumbai 1994; 41.

64. Singh RG. Experimental Evaluation of Diuretic Action of Herbal Drug Tribulus terrestris on albino rats. Jour. Of Res \& Edu. In Indian Medicine 1991; $10(1) ; 19-21$

65. Gujral, M.L., Saxena, P.N. and Mishra, S.S. An experimental study of the comparative activity of indigenous diuretics. J Indian Med Assoc. 1955; 25(2): 49

66. Tariq A. L. and Reyaz A. L. Terminalia chebula: A treatment against pathogenic Proteus vulgaris strains associated with urinary tract infections. Int. J. Res. Ayurveda Pharm2013; 4(4): 560-563. http:// dx.doi.org/10.7897/2277-4343.04422

67. Chattopadhyay RR, Bhattacharya SK, Anwesa B, Premananda B, Nitish Kumar P. Evaluation of antibacterial properties chebulic myrobalan (fruit of Terminalia chebula Retz.) extract against methicillin resistant Staphylococcus aureus and trimethoprim- 
sulphamethaxozole resistant uropathogenic E. coli. African journal of plant science 2009; 3(2): 25-29.

68. Khan KH. The effect of regular intake of Terminalia chebula on oxidative stress in mice originated from Salmonella typhimurium. EurAsia J BioSci. 2009;3:113-121.

69. Sumit Varshney, Puneet Varshney, Sandeep K. Dash, Manoj K. Gupta, Amit Kumar, Basanti Bist and Arvind Sharma,Antibacterial activity of fruits of Terminalia chebula and Terminalia belerica against mastitis field isolates, Medicinal Plants, September 2012); 4(3)

70. Tambekar DH and Dahikar SB, Exploring antibacterial potential of some ayurvedic preparations to control bacterial enteric infections, J. Chem. Pharm. Res.,2011;2(2):24-29.

71. Praveen Kumar S.V, Sandeep M, Kamal D, Nishanth B.C, Megharaj H.K, Prashith Kekuda T.R et. al. Antibacterial and Anthelmintic activity of selected fermented Ayurvedic herbal formulations. Drug Invention Today 2010; 2(7):347- 48

72. Pankaj Dixit, Praveen Sharma, Dinesh Kumar Jain, Vikas Jharia. Systematic evaluation of antiulcer activity of herbal formulation Chandanasava in rats. Asian pacific journal of tropical disease 2012; S192-S196.

73. Sekar S, Mariappan S. Traditionally fermented biomedicines, arishtas and asavas from Ayurveda. Ind J Trad Knowl 2008; 7(4):548-56

74. Annadurai Vinothkanna, Subbiah Mariappan, Soundarapandian Sekar. Tracking the organoleptic and biochemical changes in the ayurvedic polyherbal and native fermented traditional medicines: balarishta and chandanasava. Int J Pharm Pharm Sci 2014; 6(9):521-26

75. Manisha Gharate, Veena Kasture. Evaluation of anti- inflammatory, analgesic, antipyretic and antiulcer activity of Punarnavasava: an Ayurvedic formulation of Boerhavia diffusa. Oriental Pharmacy and Experimental Medicine 2013; 13(2):121-26

76. Mehdi Bin Samad, Ninadh Malrina D'Costa, Ashraf-ul Kabir, J.M.A.Hannan. Investigation on Central and PeripheralAnalgesic and AntiInflammatory Activity of Punarnavasava, an
Ayurvedic Preparation. British Journal of Pharmaceutical Research 2013;3(1):146-62

77. Vineeth T, Deepak $M$ and AB Rema Shree. Antibacterial Effect of Boerhavia Diffusa and Punarnavasavam on Urinary Tract Infection (UTI) causing pathogens. World Journal of Pharmaceutical Research 2014; 3(5): 423-37.

78. Priya Bhat, Gajanana Hegde, An observational clinical study on the management of mutrakrichchra (lower urinary tract infection) Ayurpharm Int J Ayur Alli Sci., Vol. 3, No. 10 (2014) Pages 275 - 281).

79. Jayalakshmi S, Arjun Patra, V.K. Lal, A.K. Ghosh. Antimicrobial activity of "Trinpanchmool" drugs. Archives of Applied Science Research 2010; 2 (3):183-87

80. Jitendra D. Khot, Dnyaneshwar. K. Jadhav. A comparative clinical study of trunapanchamula kwatha and haritakyadi kwatha in the management of pittaja mutrakricchra. Ayushdhara 2015; 2(1):43-52

81. Jayalaksmi S, Ashoke $\mathrm{K}$ Ghosh, Birendra Shrivastava, Rajeev K Singla. Preliminary Investigation of Antipyretic Activity of Trinpanchmool Extracts. International Journal of Phytomedicine 2011; 3:147-50

82. Rathi B, Rathi R. Quantitative analysis of Medicinal plants used by the traditional healers of Karanja block of Wardha district for treating musculoskeletal disorders, International Journal of Ayurvedic Medicine (IJAM), 2020, 11(2): 175-183

83. Chauhan N, Kumar D, Kasana MS. Medicinal plants of Muzaffarnagar district used in treatment of urinary tract and kidney stones, International journal of Traditional Medicine, 2009;8(2):191-195

84. Sarguna S Sundaram, K Suresh and S Prasanna Sundaram. Traditional knowledge of medicinal plants used to treat kidney related diseases in selected areas of Madurai district, Tamil Nadu, India, Journal of Medicinal Plants Studies. 2019; 7(4): 250-253

85. Narsingh Verma, Kalpana, Ajay Verma, Role of 'Gokshuradi Yog' in Early Symptomatic Relief in Urinary Tract Infection in Children, Annals of International Medical and Dental Research, Vol (1), Issue (1), Pages 18-20. 